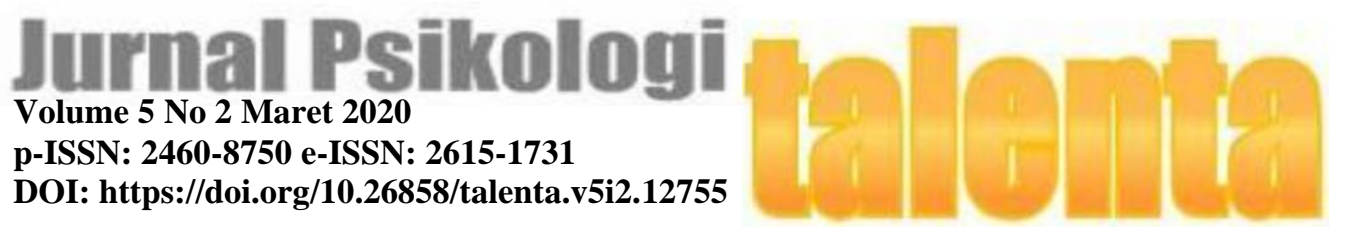

\title{
Relaxation in Children: Method to Reduce the Negative Effects of Using Gadgets on the Alpha Generation
}

\author{
Laelatus Syifa Sari Agustina ${ }^{1}$, Afia Fitriani², Mahardika Supratiwi ${ }^{\mathbf{3}}$ \\ 1 S-1 Prodi Psikologi Universitas Sebelas Maret; Jl.Ir. Sutami No.36 A Surakarta \\ 2 S-1 Prodi Psikologi Universitas Sebelas Maret; Jl.Ir. Sutami No.36 A Surakarta \\ 3 S-1 Pendidikan Luar Biasa Universitas Sebelas Maret; Jl.Ir. Sutami No.36 A Surakarta
}

Universitas Sebelas Maret;

Email: *1 laelatussyifa.sa@staff.uns.ac.id,2 afia.fitriani@staff.uns.ac.id, 3 mahardika.s@staff.uns.ac.id

Abstrak. Generasi Alpha adalah generasi yang memiliki tingkat keakraban yang tinggi dengan teknologi, bahkan sudah dialami sejak bayi. Generasi ini sangat akrab dengan penggunaan laptop, komputer, HP, tab dan perangkat gadget yang sangat dipenuhi stimulus audia dan visual dalam sekali tempo. Anak generasi Alpha biasa menghabiskan waktu dengan gadget secara berlebih tanpa menyadarinya. Pemakaian gadget pada generasi alpha bukan tidak membawa resiko, anak yang bermain video game menunjukkan fungsi visual yang lebih aktif menghasilkan gejala yang mirip dengan hiperaktivitas dan menurunkan daya konsentrasi. Pemakaian gadget bahkan dapat menurunkan prestasi anak didunia akademik. Untuk meningkatkan daya konsentrasi, bisa dilakukan dengan mengaktifkan sensasi dalam tubuh, sehingga tubuh berada dalam keadaan yang rileks dan suasana yang menyenangkan, karena dalam keadaan tegang seseorang tidak akan dapat menggunakan otaknya dengan maksimal. Relaksasi merupakan sebuah teknik untuk menenangkan fisik maupun batin. Relaksasi dipandang efektif mengurangi dampak negatif sebagai akibat dari pengaruh penggunaan gadget. Metode yang digunakan adalah dengan melakukan literatur review. Penelitian ini bertujuan untuk melihat pengaruh relaksasi dan menyusun instrumen relaksasi yang tepat dilakukan kepada anak. Hasil menunjukkan bahwa relaksasi dapat meningkatkan atensi dan menurunkan kecemasan pada individu. Dan dalam prosesnya, relaksasi meliputi 3 fase yaitu loosening up, letting go dan going to close.

Keyword : relaksasi, gadget, generasi alpha, anak

Abstract. Alpha generation is a generation that has a high level of familiarity with technology, even experienced since infancy. This generation is very familiar with the use of laptops, computers, cellphones, tabs and gadget devices that are full of audio and visual stimuli at one time. Alpha generation children usually spend more time with gadgets without realizing it. The use of gadgets in alpha generation does not carry risks, children who play video games show more active visual functions producing symptoms similar to hyperactivity and decreasing concentration power. The use of gadgets can even reduce children's achievement in the academic world. To increase the power of concentration, it can be done by activating sensations in the body, so that the body is in a relaxed state and pleasant atmosphere, because in a tense state a person will not be able to use his brain to the fullest. Relaxation is a technique for physical and mental calm. Relaxation is seen as effective in reducing negative impacts as a result of the influence of the use of gadgets. The method used is to do a literature review. This study aims to look at the effects of 
relaxation and develop appropriate relaxation instruments performed on children. The results show that relaxation can increase attention and reduce anxiety in individuals. And in the process, relaxation includes 3 phases, namely loosening up, letting go and going to close.

Keyword: relaxation, gadgets, alpha generation, children

\section{Pendahuluan}

Gadget adalah perangkat penting dimana banyak orang bergantung padanya dalam era milenium ini. (Yee, Seok, Hashmi, Teng, \& Indran, 2016). Teknologi digital menjadi satu aspek penting dalam faktor yang menginvasi banyak tahapan perkembangan anak. banyak aspek perkembangan anak yang harus melakukan penyesuaian terhadap lingkungan yang sudah berbasis teknologi, misalkan mainan, hubungan dengan orang tua dan lingkungan sekitar (Alia \& Irwansyah, 2018). Generasi yang lebih muda diminta untuk menggunakannya lebih sering daripada generasi sebelumnya. Menurut O'Connor (2013), bayi tertarik untuk mengakses teknologi dan layar. Penelitian yang dilakukan terhadap 2.714 orang tua di asia tenggara yang memiliki anak berusia $3-8$ tahun pada orang tua (Singapura, Malaysia, Thailand, Indonesia dan Filipina) menunjukkan bahwa kebanyakan mereka memperbolehkan anak bermain gadget untuk tujuan edukasi namun kenyataanya dari hasil survey menunjukkan bahwa sebagian besar anak mereka menggunakannya untuk hiburan dan game (Alia \& Irwansyah, 2018). Secara keseluruhan mereka menggunakan gadget dengan duduk atau berbaring yang diistilahkan dengan "sedentary behavior" untuk menjelaskan kondisi ini.
Temuan mendukung fakta bahwa saat ini anak-anak memiliki gaya hidup yang lebih santai. Selain itu juga psikososial adalah faktor lain yang berkontribusi terhadap penggunaan gadget. Teknologi yang memungkinkan untuk menghadirkan stimulus suara dan visual di saat yang bersamaan membuat anak mampu untuk mempelajari banyak hal dalam satu waktu (Alia \& Irwansyah, 2018). Anak-anak tertarik pada animasi dan musik dari layar, dengan demikian gadget selalu menjadi metode alternatif untuk menjadi "pengasuh anak" agar anak -anak tetap diam. Mereka berinteraksi dengan layar daripada dengan orang tua atau teman sebaya mereka. Fenomena ini bisa menyebabkan speech delay, gangguan tidur, lemahnya sosial skill dan bahkan brain damage, khususnya pada anak yang lebih kecil (NAEYC, Fred Rogers Canter, 2012). Lebih khusus lagi, Arora dkk., pada penelitiannya di tahun 2014 (Kasim, Murdiana, \& Fakhri, 2018) menemukan bahwa peningkatan dalam penggunaan teknologi seperti menggunakan internet untuk menonton televisi, bermain game, penggunaan komputer dan penggunaan smartphone memunculkan efek berbahaya yang cenderung mengakibatkan kurangnya waktu tidur dan tidur larut malam . 
Menurut penelitian ditemukan bahwa screen time terbukti mengurangi rentang perhatian pada anak pre-school. Stimulus screen menyediakan baik stimulus visual maupun stimulus auditori. Tontonan yang pasif tanpa interaksi dengan manusia memiliki dampak yang negatif. (Zivan, Bar, Jing, Farah, \& HorowitzKraus, 2019). Meningkatnya waktu screen time menurunkan fungsi konektifitas dalam otak yang berhubungan dengan kemampuan perhatian pada anak umur 8-12 tahun. Kondisi animasi pada layar lebih menarik dan pasif daripada ilustrasi pada kegiatan mendongeng, yang dihubungkan pada kurangnya imajinasi dan perhatian. Pola aktifitas otak menunjukkan berkurangnya atensi pada anak yang terpapar layar (Zivan, Bar, Jing, Farah, \& Horowitz-Kraus, 2019).

Terdapat ketidakkonsistenan hasil yang mengkalrifikasi apakah screen times baik atau buruk pada anak (BHF National Centre, p.3). sebagian besar orang tua melaprkan bahwa menonton program edukasi di televisi untuk anak membantu proses belajar (PeisnerFeinberg, 2004) sedangkan studi terbaru menunjukkan bahwa screentime menurunkan prestasi akademik, fitness skore rendah pada perilaku prososial dan self esteem dan mengarah pada gaya hidup sedentary karena anak-anak kurang terpapar kegiatan di luar ruangan.

Rahman juga menuliskan bahwa beberapa efek samping dari pemakaian teknologi digital adalah: menurunnya prestasi belajar karena penggunaan yang berlebihan, perkembangan otak tidak maksimal karena stimulasi perkembangan tidak seimbang; masalah kesehatan mata (seharusnya screen time dibatasi maksimal 2 jam per hari); masalah konsentrasi (sebentar-bentar melihat dan mengecek gadget); masalah tidur, jumlah waktu tidur, dan kualitas tidur yang kurang (akibat isi dari tontonan) (Alia \& Irwansyah, 2018). Padahal pada anak usia sekolah, prestasi belajar seorang siswa sangat dipengaruhi oleh kemampuan menyerap pelajaran yang diberikan kemampuan menyeraap pelajaran tersebut, baik yang diperoleh karena memperhatikan apa yang diajarkan guru maupun dari hasil upaya belajar sendiri ditentukan oleh kemampuan belajar siswa (Mulyana, Izzati, \& Rahmasari, 2013)

Penelitian ini bertujuan untuk mengetahui apakah metode relaksasi dapat mengurangi dampak negatif khususnya mengenai permasalahan atensi dan kecemasan yang disebabkan oleh penggunaan gadget pada anak melalui literatur review. Manfaat penelitian yg mendasari hasil penelitian ini dapat menjadi acuan pembentukan instrumen relaksasi untuk anak. Hal ini dikarenakan penggunaan gadget yang tidak bisa dihindarkan pada anak generasi saat ini.

Teknik terapi relaksasi progresif merupakan terapi non farmakologis dalam merilekskan otot dimana ketika ada ketegangan otot dikurangi dengan mengaktifkan sistem saraf parasimpatik sehingga terjadi efek rileks pada tubuh. Hal ini membantu pada orang insomnia, kurang konsentrasi dan emosi (Mariyana, 2019). Progresive muscle relaxation yang dilakukan 
pada anak-anak di Bangladesh menunjukkan kemampuan dalam menurunkan kecemasan dan sekaligus meningkatkan kemampuan atensinya. Relaksasi di terima secara universal karena memiliki efek yang berkelanjutan (Srilekha S, 2013). Oleh karena itu literatur review ini ingin melihat apakah efek relaksasi mampu untuk mereduksi akibat negatif dari efek penggunaan gadget.

\section{Metode}

Studi dimulai dengan sistematis untuk mengidentifikasi jurnal online tentang berbagai penelitian yang terkait dengan relaksasi. Peneliti menggunakan database elektronik google scholar dan sciencedirect dengan kata kunci relaksasi, screentime terlebih dahulu, baru melakukan seleksi judul yang menggunakan kata gadget, perhatian dan anak.
Kriteria inklusi pada studi ini adalah (a) hanya pada studi empiris terkait dengan pelaksanaan teknik relaksasi (b) studi tersebut menggunakan desain metode eksperimen. Analisis data digunakan untuk menjawab pertanyaan utama dalam penelitian, yaitu : "Apakah relaksasi mampu mengurangi dampak negatif khususnya permasalahan atensi dan kecemasan dari penggunaan gadget?" selain itu, studi ini juga mengungkapkan teknik relaksasi yang bisa digunakan. Tujuan utama dalam penelitian ini adalah untuk mengeksplorasi, merangkum, dan melakukan sintesis pada literatur yang telah ada dalam memahami teknik relaksasi pada anak. Telaah naratif dalam studi ini juga digunakan untuk memetakan teknikteknik relaksasi.

\section{Hasil}

Tabel 1. Rangkuman reviu studi

\begin{tabular}{|c|c|c|c|c|c|}
\hline No. & $\begin{array}{l}\text { Penulis ; } \\
\text { Tahun } \\
\text { Terbit }\end{array}$ & Judul & Tujuan & $\begin{array}{l}\text { Metode; } \\
\text { sampel; } \\
\text { setting }\end{array}$ & Hasil \\
\hline 1 & $\begin{array}{l}\text { Srilekha S.; } \\
\text { Soumendra } \\
\text { S.; } \\
\text { Chattopadh } \\
\text { yay P.K. } \\
2013\end{array}$ & $\begin{array}{l}\text { Effect of Muscle } \\
\text { Relaxation Training as } \\
\text { a Function of } \\
\text { Improvement } \\
\text { Attentiveness } \\
\text { Children } \\
\end{array}$ & $\begin{array}{lr}\text { Mengukur } & \\
\text { kemampuan } & \text { perhatian } \\
\text { electrical } & \text { muscle } \\
\text { potentiality } & \text { dan } \\
\text { variabek dari } & \text { kulit } \\
\text { (untuk mengindikasi } \\
\text { emosionall } & \text { yang } \\
\text { tinggi) } & \end{array}$ & $\begin{array}{l}\text { Eksperimen, } \\
\text { naka umur 9- } \\
12 \text { tahun, } \\
\text { Grup } \\
\text { eksperimen : } \\
\text { mendapatkan } \\
\text { pelatihan } \\
\text { ekperimen } \\
\text { APMR } \\
\text { (Abbreviated } \\
\text { Progressive } \\
\text { Muscle } \\
\text { Relaxation ) } \\
\text { selama 15 } \\
\text { menit perhari, } \\
3 \text { kai dalam } \\
\text { seminggu, } \\
\text { selama 2 } \\
\text { bulan dengan } \\
\text { guide dari } \\
\text { trainer yang } \\
\text { berkualifikasi } \\
\text { Follow up } \\
\text { dua bulan }\end{array}$ & $\begin{array}{l}\text { Menunjukkan relaksasi baik untuk } \\
\text { menurunkan kecemasan ran dan } \\
\text { kemampuan perhatian. }\end{array}$ \\
\hline
\end{tabular}




\begin{tabular}{|c|c|c|c|c|c|}
\hline & & & & setelahnya. & \\
\hline 2 & $\begin{array}{l}\text { Olievia } \\
\text { Prabandini } \\
\text { Mulyana, } \\
\text { Umi } \\
\text { Anugerah } \\
\text { Izzati, } \\
\text { Diana } \\
\text { Rahmasari }\end{array}$ & $\begin{array}{l}\text { Penerapan Relaksasi } \\
\text { Atensi untuk } \\
\text { Meningkatkan } \\
\text { Konsenstrasi Belajar } \\
\text { pada Siswa SMK }\end{array}$ & $\begin{array}{l}\text { Untuk melihat apakah } \\
\text { relaksasi atensi dapat } \\
\text { meningkatkan } \\
\text { konsentrasi belajar }\end{array}$ & $\begin{array}{l}\text { Pre-test and } \\
\text { post-test } \\
\text { group design. } \\
\text { Sample: } \\
\text { siswa SMK , } \\
30 \text { untuk } \\
\text { kelompok } \\
\text { eksperimen } \\
\text { dan } 30 \text { untuk } \\
\text { kelompok } \\
\text { kontrol } \\
\text { Pengukuran } \\
\text { atensi } \\
\text { diberikan } \\
\text { melalui tes } \\
\text { army alpha }\end{array}$ & $\begin{array}{l}\text { Relaksasi atensi dapat meningkatkan } \\
\text { konsentrasi belajar pada siswa SMK. } \\
\text { Perogram relaksasi atensi didasarkan } \\
\text { pada teori relaksasi atensi dari Robert } \\
\text { H. McKim dengan tiga tahapan dasar, } \\
\text { yaitu loosening up (peregangan), } \\
\text { letting go (pembebasan ketegangan), } \\
\text { going to close (pendekatan masalah) }\end{array}$ \\
\hline 3 & $\begin{array}{l}\text { Eric } \\
\text { Pfeifer, } \\
\text { Henrike } \\
\text { Fiedler, } \\
\text { Marc } \\
\text { Wittmann, } \\
2019\end{array}$ & $\begin{array}{l}\text { Enhanced Relaxation } \\
\text { in Students after } \\
\text { Combined Depth } \\
\text { Relaxation Music } \\
\text { Therapy and Silence in } \\
\text { a Natural Setting }\end{array}$ & $\begin{array}{l}\text { Untuk } \\
\text { membandingkan } \\
\text { persepsi } \\
\text { "hening" pada sesi } \\
\text { relaksasi waktu } \\
\text { "hening" pada setting } \\
\text { alami }\end{array}$ & $\begin{array}{l}\text { Mahasiswa } \\
\text { dengan dibagi } \\
\text { dalam } 7 \\
\text { kelompok , } \\
\text { mengikuti } \\
\text { sesi 1 dan sesi } \\
2 \\
\text { Alat ukur } \\
\text { STSS (State } \\
\text { scales on } \\
\text { subjective } \\
\text { time, self, } \\
\text { space) } \\
\text { Level of } \\
\text { relaxation }\end{array}$ & $\begin{array}{l}\text { Keheningan efektif untuk } \\
\text { meningkatkan kondisi relaks. Ketika } \\
\text { digabungkan dengan musik, } \\
\text { kelompok grup tersebut merasakan } \\
\text { waktu berjalan lebih lambat daripada } \\
\text { keheningan yang dilakukan di setting } \\
\text { alamiah } \\
\text { Sesi pelaksanaan terapi: peserta } \\
\text { diminta untuk menonaktifkan mobile } \\
\text { phone, dan jam tangan. } \\
\text { Sesi diguide oleh profesional musik } \\
\text { terapi, memanfaatkan ucapan untuk } \\
\text { membujuk peserta melakukan depth } \\
\text { relaxation dengan melakukan } \\
\text { gerakan, dan hitungan mundur yang } \\
\text { bertujuan untuk menumbuhkan } \\
\text { kepekaan seseorang terhadap } \\
\text { perasaan kenyamanan fisik }\end{array}$ \\
\hline 4 & $\begin{array}{l}\text { Nursalam, } \\
\text { Kristiawati, } \\
\text { Yuni S.A., } \\
\text { Nuzul } \\
\text { Qur'aniati, } \\
\text { Dyah Surya } \\
\text { K. , } 2007\end{array}$ & $\begin{array}{l}\text { Teknik relaksasi } \\
\text { Imagery terhadap } \\
\text { Respons Penerimaan } \\
\text { (Psikologis dan } \\
\text { Biologis) dalam } \\
\text { Prosdur Invasif pada } \\
\text { Anak Usia Sekolah }(8- \\
12 \text { tahun) }\end{array}$ & $\begin{array}{l}\text { Untuk melihat } \\
\text { pengaruh teknik } \\
\text { imagery relaksasi pada } \\
\text { psikological dan } \\
\text { biological acceptance } \\
\text { respon. }\end{array}$ & $\begin{array}{l}\text { Anak usia 8- } \\
12 \text { tahun } \\
\text { berjumlah } 20 \\
\text { orang, } \\
\text { Menggunakan } \\
\text { metode two } \\
\text { group pre test } \\
\text { post test } \\
\text { design, }\end{array}$ & $\begin{array}{l}\text { Teknik relaksasi dapat menurunkan } \\
\text { stres hospitalisasi yang terjadi pada } \\
\text { anak melalui roses kognisi dan emosi }\end{array}$ \\
\hline 5 & $\begin{array}{l}\text { Rina } \\
\text { Mariyana, } \\
2019\end{array}$ & $\begin{array}{lr}\text { Efektivitas } & \text { Teknik } \\
\text { Relaksasi } & \text { Progresif } \\
\text { dalam } & \text { Mengurangi } \\
\text { Kesulitas } & \text { Tidur pada } \\
\text { Remaja } & \end{array}$ & $\begin{array}{lr}\text { Untuk mengetahui } \\
\text { pengaruh teknik } \\
\text { relaksasi progresif } \\
\text { pada kesulitan tidur } \\
\text { yang dialami remaja }\end{array}$ & $\begin{array}{l}\text { Remaja } \\
\text { berjumlah } 20 \\
\text { orang, } \\
\text { Menggunakan } \\
\text { metode two } \\
\text { group pre test } \\
\text { post test } \\
\text { design, }\end{array}$ & $\begin{array}{l}\text { Dalam relaksasi otot (progresif } \\
\text { muscle relaxation) sendiri, individu } \\
\text { akan diberikna kesempatan untuk } \\
\text { mempelajari bagaimana cara } \\
\text { menegangkan sekelompok otot } \\
\text { tertentu kemudian melepaskan } \\
\text { ketegangan itu. }\end{array}$ \\
\hline 6 & $\begin{array}{l}\text { Yulia } \\
\text { Fitriani, } \\
\text { Asmadi } \\
\text { Alsa }\end{array}$ & $\begin{array}{l}\text { Relaksasi autogenik } \\
\text { untuk meningkatkan } \\
\text { reguasi emosi pada } \\
\text { siswa SMP }\end{array}$ & $\begin{array}{lr}\text { Untuk } & \text { melihat } \\
\text { pengaruh } & \text { relaksasi } \\
\text { autogenik } & \text { pada } \\
\text { regulasi emosi remaja }\end{array}$ & $\begin{array}{l}\text { Two group } \\
\text { pre test post } \\
\text { tes design, } \\
\text { Siswa umur } \\
12-15 \text { tahun }\end{array}$ & $\begin{array}{l}\text { Individu yang baik regulasi emosinya } \\
\text { menunjukkan fungsi kognitif yang } \\
\text { lebih tinggi. Hal ini dikaitkan dengan } \\
\text { kurangnya kemampuan konsentrasi. } \\
\text { Tujuan relaksasi autogenik adalah } \\
\text { mengembangkan hubungan isyarat } \\
\text { verbal dan kondisi tubuh yang tenang } \\
\text { dimana tidak ada kondisi fisik yang } \\
\text { aktif saat melakukannya. } \\
\text { Imajinasi visual dan sugesti verbal } \\
\text { yang membantu tubuh merasa hangat, } \\
\text { berat dan santai merupakan standar } \\
\text { latihan relaksasi autogenik. } \\
\text { Prosedur relaksasi autogenikk : } \\
\text { eksplorasi diri yang membantu } \\
\text { individu menyadari pengaruh pikiran } \\
\text { negatifnya terhadap perasaan, }\end{array}$ \\
\hline
\end{tabular}


fisiolgis dan proses perilakunya yang terjadi saat individu merespon stimulus dari lingkungan. hal ini dilakukan melalui proses kognitif. Proses selanjutnya adalah dengan menekankan sugesti pada diri sendiri untuk lebih tenang dan rileks.

Proses ketiga adalah memberikan tugas rumah untuk praktik secara mandiri.

\section{Diskusi}

Hasil review menunjukkan bahwa relaksasi mampu untuk membantu individu meregulasi emosinya dan meningkatkan kemampuan kognitif termasuk daya konsentrasi seseorang. Mekanisme ini di jelaskan oleh Fitriani (2015) (Fitriani \& Alsa, 2015) tentang dampak yang menguntungkan dari praktek relaksasi otot progresif singkat (APMR/ Abbreviated progressive muscle relaxation) untuk periode yang singkat pula (sekitar 2 bulan) dicatat baik dalam bentuk subjective dan objective dari pengukuran emosional dan juga menunjukkan perubahan hasil performansi perhatian. Hasilnya mengungkapkan adanya peningkatan yang signifikan dalam skor basal. penilaian intervensi menunjukkan efek yang kuat dan persisten pada anak-anak, berupa pengurangan kecemasan dan peningkatan perhatian. Pengurangan ketegangan otot yang dimediasi oleh praktek relaksasi dalam jangka waktu yang lama dapat memberikan dampak yang pasti pada perubahan fokus perhatian dari pemikiran yang memicu kecemasan (Fitriani \& Alsa, 2015).

Pada sistem saraf manusia terdapat sistem saraf pusat dan sistem saraf otonom. Sistem saraf pusat mengendalikan gerakan yang dikehendaki, sedang sistem saraf otonom berfungsi mengendalikan gerakan otomatis. Sistem saraf ototnom terdiri dari sistem saraf simpatis dan sistem saraf parasimpatis yang kerjanya saling berlawanan dimana siste saraf simpatis meningkatkan rangsangan dengan memacu meningkatkan detak jantung dan pernafasan, sedangkan sistem parasimpetis akan menstimulasi turunnya semua fungsi yang dinaikkan oleh saraf simpatis. Sistem akan berfungsi secara normal dalam keseimbangan, tetapi bertambahnya aktivitas sistem yang lain akan menghambat atau menaikkan sistem yang lain. Pada waktu individu mengalami ketegangan dan kecemasan yang bekerja adalah sistem saraf simpatis, sedangkan pada waktu relaksasi yang bekerja adalah sistem saraf parasimpatis, dengan demikian relaksasi dapat menekan rasa tegang dan rasa cemas dengan cara resiprok, sehingga timbul counter conditioning dan penghilangan (Prawitasari, dalam Purwanto, 2008).

Apabila Individu melakukan relaksasi ketika ia mengalami ketegangan atau kecemasan, maka reaksi-reaksi fisiologis yang dirasakan individu akan berkurang, sehingga la akan merasa rileks. Apabila kondisi fisiknya sudah rileks, maka 
kondisi psikisnya juga tenang (Lichstein, dalam

Purwanto, 2008).

Pada review jurnal diatas menunjukkan bahwa relaksasi mampu untuk menurunkan kecemasan dan meningkatkan fungsi kognitif seperti hal nya atensi pada individu. Prosedur yang diberikan mencakup

a. Melibatkan proses otot

b. Melibatkan Sugesti diri

c. Penggunaan audio music/ kondisi alam yang bisa membantu proses relaksasi

d. Melibatkan guide yang membantu sugesti pada individu

Tidak banyak yang membahas tentang prosedur relaksasi pada anak, namun relaksasi juga bisa diberikan dengan permainan. Metode bermain merupakan media mengembangan diri dan komunikasi natural anak (Sweeney, Baggerly, \& Ray, Ray, 2014). Melalui bermain anak memiliki kesempatan untuk mengekspresikan apa yang dirasakannamun anak itu suka bermain. Permainan ini bisa berupa permainan peran dalam relaksasi seperti bermain pura-pura menjadi patung, atau hewan.

Dari literature review ditemukan bahwa relaksasi memiliki dampak psikologis maupun fisik. intervensi melalui pengendalian reaksi tubuh ini mampu meregulasi emosi mereka sehingga mengurangi kecemasan dan membantu seseoran guntuk mempertahankan konsentrasinya, dimana kedua hal ini seringkali dialami generasi Alpha akibat penggunaan gadget.
Saran peneliti selanjutnya adalah, literatur ini merupakan studi pustaka yang perlu di tindak lanjuti dengan studi yang bersifat empiris untuk menguatkan kesimpulan yang dihasilkan.

\section{DAFTAR PUSTAKA}

Alia, T., \& Irwansyah. (2018). Pendampingan Orang Tua pada Anak USia Dini dalam Penggunaan Teknologi Digital. A Juornal of Language, Literature, Culture, and Education, 65-78.

Fitriani, Y., \& Alsa, A. (2015). Relaksasi Autogenik untuk Meningkatkan Regulasi Emosi pada Siswa SMP. Gadjah Mada Journal of Profesional Psychology, 149-162.

Kasim, M. I., Murdiana, S., \& Fakhri, N. (2018). Pengaruh Stres Akademik Dan Kecanduan Internet Dengan Kualitas Tidur Pada Mahasiswa Di Kota Makassar. Proceedings of Psychology" Cyber Effect: Internet Influence on Human Life", 83-95.

Mariyana, R. (2019). Efektivitas Teknik Relaksasi Progresif dalam Mengurangi Kesulitas Tidur pada Remaja. Jurnal Endurance : Kajian Ilmiah Problema Kesehatan .

Mulyana, o. P., Izzati, U. A., \& Rahmasari, D. (2013). Penerapan Relaksasi Atensi untuk Meningkatkan Konsentrasi Belajar pada Siswa SMK . Jurnal Psikologi: Teori \& Terapan , 103-113.

NAEYC, Fred Rogers Center. (2012). Technology and interactive media as tools in early childhood programs serving children from birth through age 8. Retrieved at May 25, 2018 from 
http://www.naeyc.org/files/naeyc/file/po

sitions/PS_technology_WEB2.pdf

Nursalam, Kristiawati, S.A, Y., Qur'aniati, N., \& K, D. S. (2007). Teknik Relaksasi Imagery Terhadap Respons Penerimaan (Psikologis dan Biologis) dalam Prosedur Invasif pada Anak Usia Sekolah (8-12 tahun). Jurnal Ners.

Pfeifer, E., Fiedler, H., \& Wittmann, M. (2019). Enhance Relaxation in Students After Combined Depth Relaxation Music Therapy and Silence in Natural Setting. The Arts in Psychotherapy, 68-76.

Purwanto, S. (2008). Mengatasi Insomnia dengan Terapi Relaksasi. Jurnal Kesehatan, 141-148.

Srilekha S, S. S. (2013). Effect of Muscle Relaxation Training as a Function of Improvement in Attentiveness in Children. Procedia Social and Behavioral Sciences, 606-613.

Yee, H. K., Seok, C. B., Hashmi, S. I., Teng, T. L., \& Indran, R. (2016). Why Gadget Usage Among Preschoolers Sould Matter to Teachers? A Pilot Study. GESJ: Education Science and Psychology.

Zivan, M., Bar, S., Jing, X., Farah, R., \& Horowitz-Kraus, T. (2019). Screenexposure and altered brain activation related to attention in preschool children: an EEG Study. Trends in Neuroscience \& Education. 